УДК 617.52+616.314.2)-053.2-007.2-053.1:614.2(477.83)/.

DOI 10.11603/2311-9624.2018.4.9750

(CI. М. Готь, Р. З. Огоновський, Х. Р. Погранична, Я. М. Ільницький, Ю. Б. Пастернак, В. С. Гриновець

Львівський національний медичний університет імені Данила Галицького

(ogonov@meta.ua pohranychna@ukr.net)

\title{
Міжобласний центр із диспансеризації та лікування дітей з уродженими вадами обличчя та щелеп у Львові як етап становлення дитячої щелепно-лицевої хірургії в Україні
}

Резюме. Початок активного розвитку дитячої щелепно-лицевої хірургії сягає глибоко в історію Львівського національного медичного університету імені Данила Галицького. Сьогодні Міжобласний центр із диспансеризації та лікування дітей з уродженими вадами обличчя та щелеп, охоплює у своій діяльності 6 областей - Львівську, Волинську, Рівненську, Тернопільську, Івано-Франківську, Закарпатську. Мета дослідження - впровадити диспансерне спостереження та лікування дітей з уродженими вадами розвитку оличчя і щелеп, а також підготувати відповідних фахівців на робочих місцях Західного регіону України.

Матеріали і методи. В історичному аспекті представлено етапи становлення, розвитку та удосконалення дитячої щелепно-лицевої хірургії на прикладі Міжобласного центру з диспансеризації та лікування дітей із уродженими вадами обличчя та щелеп у Львові.

Результати досліджень та іх обговорення. 31992 р. Міжобласний центр із диспансеризації та лікування дітей з уродженими вадами обличчя та щелеп очолив професор Готь Іван Мирославович. Під його керівництвом проводяться розробка і постійна модернізація протоколів хірургічного лікування у центрі, що повністю відповідають сучасним світовим тенденціям надання допомоги дітям 3 уродженими незрощеннями обличчя. Основними завданнями центру є чіткий облік хворих із даною патологією, фахове комплексне лікування та диспансерне спостереження, вчасне проведення коригувальних операцій, багатоетапне ортодонтичне лікування.

Висновки. Характер патології, віковий аспект пацієнтів, специфіка хірургічної тактики та особливості ведення післяопераційних хворих свідчать про необхідність організації спеціалізованих стаціонарів на базі дитячих клінічних лікарень або ліжок у хірургічних відділеннях дитячих лікарень для забезпечення надання повноцінної та адекватної медичної допомоги дітям з патологією щелепно-лицевої ділянки, зменшення та уникнення ускладнень різного характеру.

Ключові слова: незрощення губи; незрощення піднебіння; уранопластика; хейлопластика.

(СИ. М. Готь, Р. З. Огоновский, Х. Р. Погранична, Я. М. Ильницкий, Ю. Б. Пастернак, В. С. Гриновец

Львовский национальный медицинский университет имени Данила Галицкого

\section{Межобластной центр диспансеризации и лечения детей с врожденными пороками лица и челюстей во Львове как этап становления детской челюстно-лицевой хирургии в Украине}

Резюме. Начало активного развития детской челюстно-лицевой хирургии уходит глубоко в историю Львовского национального медицинского университета имени Даниила Галицкого. Сегодня Межобластной центр диспансеризации и лечения детей с врожденными пороками лица и челюстей, который охватывал в своей деятельности 6 областей - Львовскую, Волынскую, Ровенскую, Тернопольскую, Ивано-Франковскую, Закарпатскую.

Цель исследования - внедрить диспансерное наблюдение и лечение детей с врожденными пороками развития лица и челюстей, а также подготовить соответствующих специалистов на рабочих местах Западного региона Украины.

Материалы и методы. В историческом аспекте представлены этапы становления, развития и совершенствования детской челюстно-лицевой хирургии на примере Межобластного центра по диспансеризации и лечения детей с врожденными пороками лица и челюстей во Львове. 
Результаты исследований и их обсуждение. С 1992 года Межобластной центр диспансеризации и лечения детей с врожденными пороками лица и челюстей возглавил профессор Готь Иван Мирославович. Под его руководством проводятся разработка и постоянная модернизация протоколов хирургического лечения в центре, что полностью соответствуют современным мировым тенденциям оказания помощи детям с врожденными несращениями лица. Основными задачами центра являются четкий учет больных с данной патологией, профессиональное комплексное лечение и диспансерное наблюдение, своевременное проведение корректирующих операций, многоэтапное ортодонтическое лечение.

Выводы. Характер патологии, возрастной аспект пациентов, специфика хирургической тактики и особенности ведения послеоперационных больных свидетельствует о необходимости организации специализированных стационаров на базе детских клинических больниц или коек в хирургических отделениях детских больниц для обеспечения предоставления полноценной и адекватной медицинской помощи детям с патологией челюстно-лицевой области, уменьшение и избежания осложнений различного характера.

Ключевые слова: расщелина губы; расщелина неба; уранопластика, хейлопластика.

\section{M. Hot, R. Z. Ogonovsky, Kh. R. Pohranychna, Ya. M. Ilnytsky, Yu. B. Pasternak,} V.S. Hrynovets

Danylo Halytskyi Lviv National Medical University

\section{Interregional Center for dispensary and treatment of children with congenital face and jaw defects in Lviv as a stage of pediatric maxillofacial surgery development in Ukraine}

Summary. The onset of active development of pediatric maxillofacial surgery goes deeply into the history of Danylo Halytskyi Lviv National Medical University. Today, the Interregional Center for dispensary and treatment of children with congenital defects of the face covering 6 regions: Lviv, Volyn, Rivne, Ternopil, Ivano-Frankivsk and Zakarpattia.

The aim of the work - to introduce dispensary observations and treatment of children with congenital defects of the face and jaws and also to teach the proper relevant specialists at places of work in the western region of Ukraine. Materials and Methods. In the historical aspect, the stages of formation, development and improvement of pediatric maxillofacial surgery were presented on the example of the Interregional Center for the examination and treatment of children with congenital defects of the face and jaws in Lviv.

Results and Discussion. Since 1992, Interregional Center for the examination and treatment of children with congenital defects of the face and jaws has been headed by Professor Ivan Hot. Under his guidance, the development and continuous modernization of surgical treatment protocols in the center is fully in line with the contemporary world tendencies of helping children with congenital facial infections. The main tasks of the center are the clear account of patients with this pathology, specialized comprehensive treatment and dispensary observation, timely corrective surgery, multi-stage orthodontic treatment.

Conclusions. The nature of the pathology, the age-old aspect of the patients, the specifics of surgical tactics and the peculiarities of management of post-operative patients, suggests the need for specialized hospitals based on pediatric clinical hospitals or beds in surgical departments of pediatric hospitals to provide full and adequate medical care for children with pathology of the maxillofacial area, reduction and avoidance of complications of different nature.

Key words: cleft lip; cleft palate; uranoplasty, cheiloplasty.

Вступ. Розвиток дитячої хірургічної стоматології та щелепно-лицевої хірургії має значну історію у Львівському національному медичному університеті імені Данила Галицького. Наказом Львівського облздороввіділу та Львівського державного медичного інституту № 597/419 від 18травня 1987 року на базі клініки і кафедри хірургічної стоматології було створено Міжобласний центр з диспансериза- ції та лікування дітей з уродженими вадами обличчя та щелеп, який охоплював у своїй діяльності 6 областей - Львівську, Волинську, Рівненську, Тернопільську, Івано-Франківську, Закарпатську. У ньому передбачено своєчасне, поступове, комплексне лікування спеціалістами-стоматологами різних профілів дітей Західного регіону України. Натхненником та організатором створення Міжобласно- 
го центру з диспансеризації та лікування дітей 3 уродженими вадами обличчя та щелеп був випускник Київського медичного стоматологічного інституту, вихованець Львівської стоматологічної школи, учень і послідовник талановитого хірурга-стоматолога, першого декана стоматологічного факультету Львівського державного медичного інституту, професора О. В. Коваля - доктор медичних наук, професор Гоцко Євстахій Володимирович [1].

Метою дослідження було впровадити диспансерне спостереження та лікування дітей 3 уродженими вадами розвитку оличчя і щелеп, а також підготувати відповідних фахівців на робочих місцях Західного регіону України.

Матеріали і методи. В історичному аспекті представлено етапи становлення, розвитку та удосконалення дитячої щелепно-лицевої хірургії на прикладі Міжобласного центру з диспансеризації та лікування дітей $з$ уродженими вадами обличчя та щелеп у Львові.

Результати досліджень та їх обговорення. Ідея створення такого центру в Львові була не нова. Своїм корінням вона сягала тих часів, коли професор Коваль Олександр Васильович, як завідувач кафедри хірургічної стоматології, працював над проблемою уроджених вад обличчя та щелеп, вивчав і удосконалював методики, організовував клініку і готував колектив відповідного профілю, а згодом науковий здобуток висвітлив у своїй докторській дисертації «Клініко-фізіологічне і експериментальноембріологічне вивчення вроджених розщілин піднебіння», яку захистив (Львів, 1967). На той час проблема уроджених вад обличчя та щелеп була дуже актуальною, їй приділяли велику увагу спеціалісти щелепно-лицевої хірургії. Цей напрямок вимагав відповідної організації клініки та високого професіоналізму хірургастоматолога. Олександр Васильович Коваль, випускник Варшавської стоматологічної академії, учень відомих професорів А. Т. Цєшиньського, І. В. Студзінського, С. Н. Вайсблата, Ю. Й. Бернадського, неодноразово пройшовши спеціалізацію з дитячої щелепно-лицевої хірургії у Варшаві, Москві, Ленінграді, Києві, налагодив у клініці Львівського державного медичного інституту проведення складних операцій, зокрема і в галузі дитячої хірургічної стоматології, а саме хірургічне лікування дітей з уродженими вадами обличчя та щелеп.

Вагомим науковим доробком у галузі дитячої хірургічної стоматології стала експериментальна модель розщілини піднебіння, яка дала можливість подальшому вивченню виникнення та профілактики уроджених ушкоджень щелеп та їх лікування, яку створив професор о. В. Коваль уперше в світі. Він підготував когорту однодумців та послідовників - Є. В. Гоцко, І. М. Готь, М. І. Мигович, Б. М. Мартинюк, М. Ф. Рождествєнська, В. В. Соболєва та ін. [2].

Значний внесок у розвиток дитячої щелепно-лицевої хірургії зробив професор $€$. В. Гоцко, наслідуючи свого вчителя-попередника у цьому нелегкому напрямку, який наполегливо продовжив і розвинув, створивши у Львському державному медичному інституті Міжобласний центр з диспансеризації та лікування дітей $з$ уродженими вадами обличчя та щелеп. Тема його докторської дисертації, яку захистив у Києві в 1988 р., була «Порівняльна оцінка хірургічного лікування вроджених розщілин верхньої губи і піднебіння». Професор Гоцко активно працював як практичний хірург-стоматолог, так і організатор і керівник - він був деканом стоматологічного факультету (19791992 рр.), завідувачем кафедри хірургічної стоматології (1972-1992 рр.) інституту. Адміністративну та громадську діяльність поєднував 3 науковою роботою, результати якої висвітлювали у наукових виданнях і періодиці. Одним із важливих моментів у розвитку дитячої хірургічної стоматології була презентація результатів роботи Міжобласного центру з диспансеризації та лікування дітей з уродженими вадами обличчя та щелеп, представлених на VII з'їді стоматологів УРСР у Львові 3-5 жовтня 1989 p. [3].

Із 1992 р. Міжобласний центр 3 диспансеризації та лікування дітей 3 вродженими вадами обличчя та щелеп очолив професор Готь Іван Мирославович. Під керівництвом професора О. В. Коваля в 1975 р. він захистив кандидатську дисертацію на тему «Порівняльна оцінка результатів хірургічного лікування вроджених незрощень піднебіння методами радикальної уранопластики і ураностафілопластики». Професор І. М. Готь продовжив і розвинув напрямок дитячої щелепно-лицевої хірургії, організувавши роботу Міжобласного центру з диспансеризації та лікування дітей із уродженими вадами обличчя та щелеп у нових сучасних умовах Львівського національного медичного університету імені Данила Галицького. Під його керівництвом професора у 2017 р. асистент Я. М. Ільницький захистив кандидатську дисертацію на тему «Кісткова пластика альвеолярного відростка та підне- 
біння комбінованим трансплантатом у дітей з вродженим незрощенням». Молоді хірургистоматологи сучасної кафедри хірургічної стоматології та щелепно-лицевої хірургії продовжують працювати та удосконалювати свою майстерність, набирати досвіду в нелегкому напрямку дитячої хірургії.

На даний час центр продовжує свою роботу. Разом з наказом Управління охорони здоров'я Львівської обласної державної адміністрації № 350 від 11.04.2011 р. та Львівським національним медичним університетом імені Данила Галицького № 1071-з від 11.04.2011 р. peорганізовано функціонування Міжобласного центру дитячої щелепно-лицевої хірургії при Стоматологічному Медичному центрі Львівського національного медичного університету імені Данила Галицького.

Одним 3 його завдань $є$ чіткий облік хворих із даною патологією у Львівській, Тернопільській, Закарпатській, Івано-Франківській областях для допомоги в оформленні соціальних пільг, передбачених законодавством України. Окрім того, за бажанням батьків, у центрі можливе фахове комплексне лікування та диспансерне спостереження, яке б включало не тільки первинне хірургічне лікування, але й лікування у педіатра, оториноларинголога, логопеда, ортодонта, психолога, лікаряхірурга-стоматолога для вчасного проведення коригувальних операцій. Це зроблено для профілактики та лікування соматичних захворювань, підготовки до хірургічного лікування, профілактики та лікування порушень носового дихання, секриторних отитів, порушень слуху, аденоїдів, тонзилітів, викривлень носових переділок, формування мовного дихання та правильної мовної функції, міогімнастики м'якого піднебіння, адаптації батьків до ситуації $з$ дитиною. Значну роль у центрі приділяють багатоетапному ортодонтичному лікуванню таких дітей, яке надають на вузькоспеціалізованій кафедрі ортодонтії Львівського національного медичного університету імені Ланила Галицького (завідувач - д. мед. наук Н. Л. Чухрай). Його суть полягає як у апаратному методі в передопераційному періоді, так і в багатофункціональному лікуванні після хірургічного лікування.

Протоколи етапного хірургічного лікування у центрі повністю відповідають сучасним світовим тенденціям надання допомоги дітям 3 уродженими незрощеннями обличчя. Нижче подано орієнтовну ії схему:
• Однобічна хейлоринопластика - у 3-6 місяців;

- Двобічна хейлоринопластика - у 4-7 місяців;

- Стафілопластика - 7-12 місяців;

- Ураностафілопластика - 12-18 місяців;

- Остеопластика альвеолярного відростка 3 реконструкцією деформацій верхньої губи та носа - 7-8 років;

- Корекція носа (відкрита ринопластика) 16 років.

Основними принципами хірургічного лікування у центрі $є$ мала інвазивність оперативного втручання з досягненням максимального функціонального та косметичного результату. Так, при проведенні операцій на верхній губі максимально використовують методики із проведенням дугоподібних розтинів, при яких можна досягти доброго естетичного ефекту із необхідним збільшенням об'єму тканин верхньої губи (хейлопластика за I. М. Готем при однобічному та двобічному незарощеннях верхньої губи) [4].

Як приклад, подаємо ілюстрацію клінічного випадку дитини, лікованої у центрі у зв'язку з однобічним незрощенням верхньої губи (рис. 1-4).

Важливим елементом реабілітації дітей 3 уродженим незарощенням піднебіння $є$ раннє відновлення роботи піднебінно-глоткового клапаня. В центрі цей етап хірургічного лікування, зазвичай, проводять у терміни 9-10 місяців та застосовують модифіковану методику I. M. Готя, яка на даний час проходить патентну експертизу. Також у центрі розроблено ме-

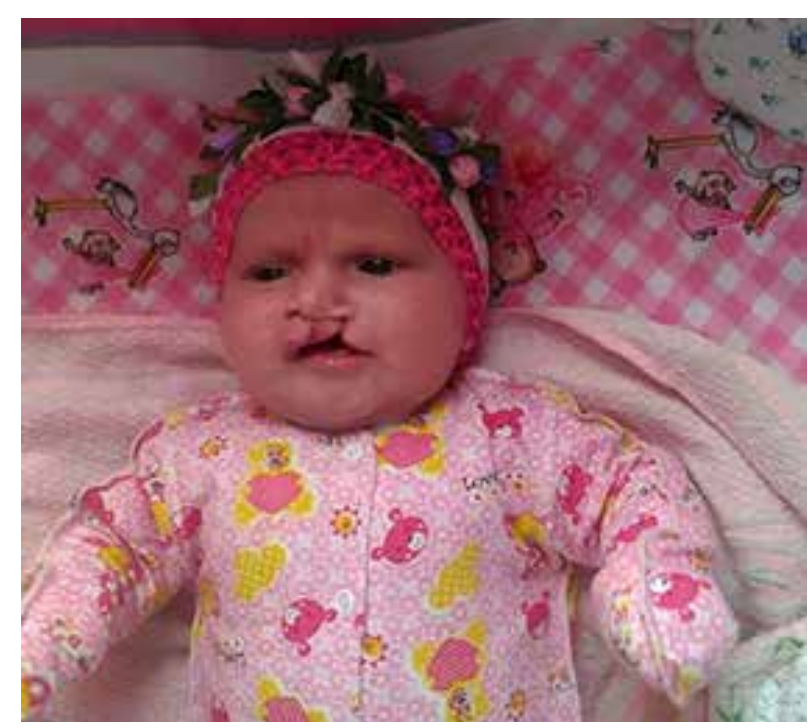

Puc. 1. Стан дитини з однобічним уродженим незарощенням верхньої губи до операції. 


\section{Хірургічна стоматологія}

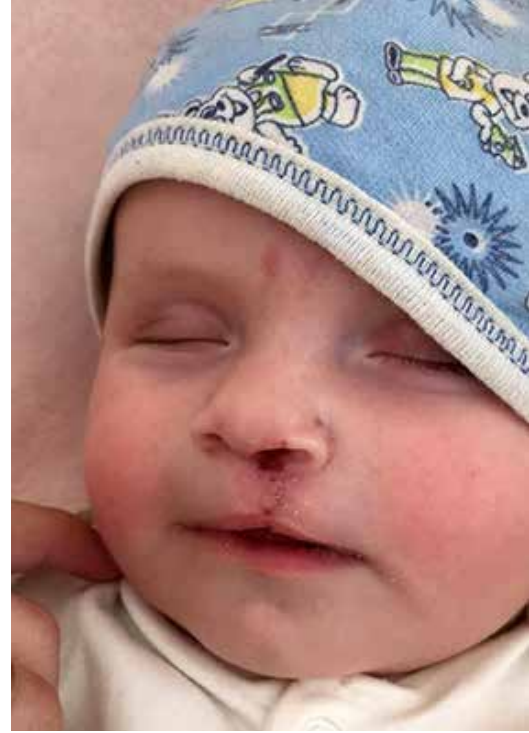

Puc. 2. Дитина через 10 днів після операції хейлопластики за I. М. Готем.

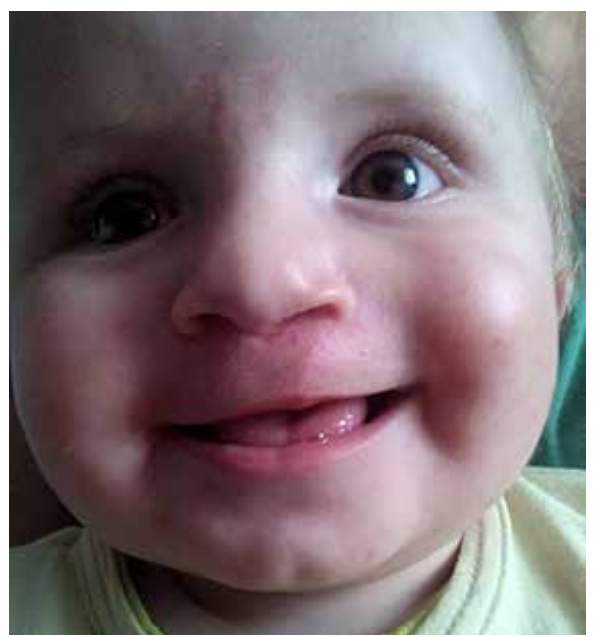

Puc. 3. Дитина через 3 місяці після хірургічного лікування.

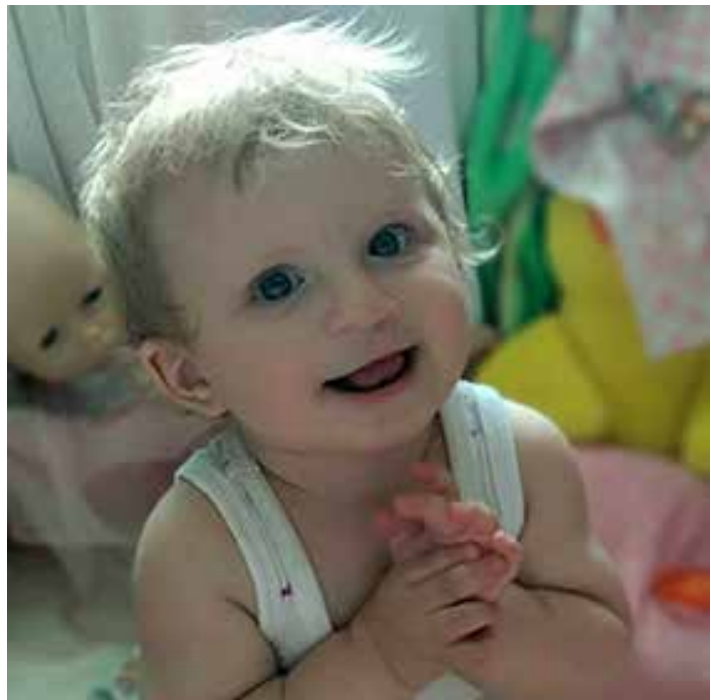

Puc. 4. Дитина через 6 місяців після хірургічного лікування. тодику альвеолоостеопластики із застосуванням комплексного кісткового трансплантата та закриття дефекту слизовою оболонкою із вестибулярного боку альвеолярного відростка, яка забезпечує його анатомічне відновлення, створює опору для м’язів верхньої губи та крил носа, забезпечує ріст та розвиток зубощелепної системи та обличчя в цілому, створює стабілізувальний ефект у косметичному та функціональному аспектах на тканини верхньої губи та носа [5]. Нижче подано ілюстрацію одного із клінічних випадків застосування вказаної методики (рис. 5, 6).

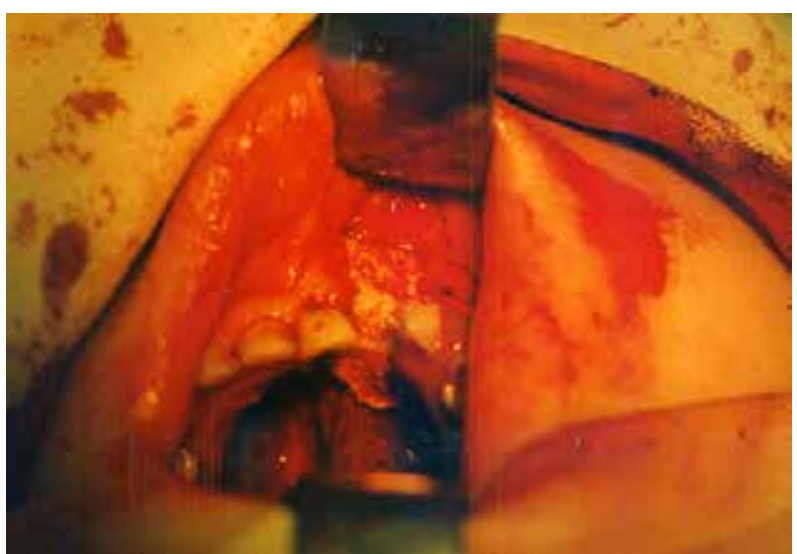

Puc. 5. Методика одномоментної остеотрансплантації та закриття уродженого дефекту альвеолярного відростка слизовою оболонкою з його вестибулярної поверхні.

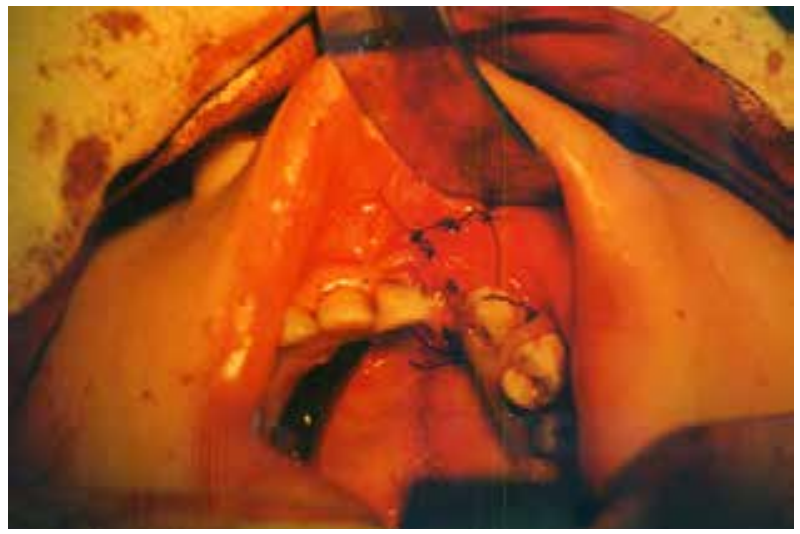

Puc. 6. Вигляд ділянки альвеолярного відростка після зашиття рани.

Висновки. 1. Діти складають значну частину пацієнтів відділення щелепно-лицевої хірургії.

2. Висока операційна активність, яку проводять під наркозом, вимагає залучення дитячих анестезіологів, яких $є$ недостатньо у дорослих лікарнях.

3. Усе вищесказане свідчить про необхідність організації спеціалізованих стаціонарів

ISSN 2311-9624. Клінічна стоматологія. 2018. № 4 


\section{Хірургічна стоматологія}

на базі дитячих клінічних лікарень або ліжок у хірургічних відділеннях дитячих лікарень для забезпечення надання повноцінної та адекватної медичної допомоги дітям із пато-

\section{Список літератури}

1. Готь I. М. Професор Олександр Васильович Коваль - перший декан стоматологічного факультету у Львові / І. М. Готь, А. В. Магльований, В. С. Гриновець. - Львів, 2007. - 108 с.

2. Стоматологічному факультетові у Львові 50 років / Р. М. Ступницький, А. В. Магльований, В. С. Гриновець, В. С. Кухта. - Львів, 2008. - 287 с.

3. Становлення та розвиток стоматологічного факультету у Львові: декан, професор Євстахій Володимирович Гоцко / [А. В. Магльований, Б. С. Зіменковський, В. С. Гриновець та ін.]. - Львів, ЛНМУ імені

\section{References}

1. Hot, I.M., Mahliovanyi, A.V., \& Hrynovets, V.S. (2007). Profesor Oleksandr Vasyliovych Koval - pershyi dekan stomatolohichnoho fakultetu u Lvovi [Professor Oleksandr Vasylyovych Koval - the first Dean of the Dentistry Faculty in Lviv]. Lviv [in Ukrainian].

2. Stupnytskyi, R.M., Mahliovanyi, A.V., Hrynovets, V.S., \& Kukhta, V.S. (2008). Stomatolohichnomu fakultetovi u Lvovi - 50 rokiv [Lviv Dentistry Faculty celebrates 50 years]. Lviv [in Ukrainian].

3. Mahliovanyi, A.V., Zimenkovskyi, B.S., Hrynovets, V.S., Stupnytskyi, R.M., \& Hot, I.M. (2008). Stanovlennia ta rozvytok stomatolohichnoho fakultetu u Lvovi: dekan, profesor Yevstahii Volodymyrovych Hotsko [Formation and development of Dental Faculty in Lviv]. Lviv: логією щелепно-лицевої ділянки, зменшення та уникнення ускладнень різного характеру, в т.ч. летальності.

Данила Галицького, 2008. - 136 с.

4. Пат. № 6883 від 31.03.1995 р. МПК: А61В 17/3209 / I. М. Готь. Спосіб хірургічного лікування однобічного незрощення верхньої губи.

5. Оцінка методу кісткової пластики піднебіння та альвеолярного відростка комбінованим трансплантатом при вроджених незрощення / Я. М. Ільницький, I. М. Готь, Р. 3. Огоновський // Здобутки клінічної і експериментальної медицини. - 2015. - № 2-3. - C. 53-57.

Danylo Halytskyi Lviv National Medical University [in Ukrainian].

4. Hot, I.M. (1995). Sposib khirurhichnoho likuvannia odnobichnoho nezroshchennia verhnioi huby [Method of surgical treatment of unilateral upper lip cleft]. Patent 6883 of March 31 [in Ukrainian].

5. Ilnytskyi, Ya.M., Hot, I.M., \& Ohonovskyi, R.Z. (2015). Otsinka metodu kistkovoi plastyky pidnebinnia ta alveoliarnoho vidrostka kombinovanym transplantatom pry vrodzshenykh nezroshchenniakh [Evaluation of hard palate and alveolar process bone grafting method with combined transplant at congenital clefts]. Zdobutky klinichnoi $i$ eksperymentalnoi medytsyny - Achievements of Clinical and Experimental Medicine, 2-3, 53-57 [in Ukrainian].

Отримано 04.09.18 